\title{
A Study on Sand Dune Forms Southeast of Jeddah, Saudi Arabia
}

\author{
W.M. Shehata, A.A. Sabtan and M.M. Ghazal \\ Faculty of Earth Sciences, King Abdulaziz University, \\ Jeddah, Saudi Arabia
}

Received: 21st Dec., 1996 Accepted: 26th Dec., 1997

\begin{abstract}
The drifting sand and dune movement pose serious geohazard on urban development and road construction in the Kingdom of Saudi Arabia. This fact initiated several research projects in a number of universities and research institutes in the Kingdom.

Two locations of inter mountain dune fields east and southeast of Jeddah were investigated and the dune forms were identified. In addition to the sand sheets, the major dune type is the reversal linear dunes coexisting with few small barchan dunes.
\end{abstract}

Detailed investigations on the linear dunes indicated that the ultimate direction of movement of the dunes is downwind along their crest line. However, during their migration, the dunes wander laterally in both directions but more in one direction than the other depending on the frequency of the prevailing wind and configuration of the surrounding mountains.

The sand from the two locations was found to be similar in their grain size parameters. Some variations, however, were observed both along the crest line and across the dune body. Mineralogically, the sand reflects the composition of the surrounding igneous, metamorphic and sedimentary rocks. The results of cone penetration tests were used to reconstruct a possible cross section for the linear dune which is slightly different from the existing hypothetical sections.

A reasonable similarity was obtained between the studied dunes and the linear dunes existing in Al Nufud but some differences were found between the sand from these dunes and the other dune forms in Al Jafurah and Ad Dahna sand seas.

The sections of the highways crossing these dune fields are either parallel or intersect the dune crest lines at small angle. The dunes, therefore, pose only minor sand drifting hazard on these highways. A forest is suggested to be established to control this hazard and minimize the waste water ponding problems.

\section{Introduction}

The eolian sand areas cover approximately one third of the Arabian Peninsula and form an important physiographic province in Saudi Arabia. Sand exists in the form of sand 
seas in the north (Al Nufud sand sea), in the east (Al Jafurah and Ad Dahna sand seas), and in the south (Al Rub al Khali). In the western part of Saudi Arabia, sand exists as dunes and sand sheets scattered along the Red Sea coast or between the mountains of Tihama along the western part of the Arabian Shield. Since sand poses natural erosionaldepositional hazards on the existing structures, roads and urbanized areas, it became necessary to study the behavior of the sand forms in the different parts of the country.

Several investigations have been made on the Nufud sand sea (Whitney, 1981; Whitney et al., 1983; Vincent, 1984), Al Jafurah sand sea (Fryberger et al., 1984; Anton and Vincent, 1986; Shehata et al., 1992), Ad Dahna sand sea (Al-Saud, 1988 and ElNozahy, 1993), and Al Rub al Khali sand sea (McClure, 1978, 1984; Edgell, 1990). Limited studies have been performed on the dunes in the western area (Binda, 1983; Zaidi, 1983), probably because of their limited severity as a natural hazard.

The objectives of this work are to present the dune types, mode of movement and properties of the dune forming sand in the central Tihama area represented by two inter mountain dune fields to the east and southeast of Jeddah. These findings will also be compared with the results of the several investigations performed on Al Jafurah and Al Nufud sand seas. A remedial measure will be suggested to solve the problem associated with the dunes and minimize the hazard related to the existing waste water flow along Jeddah-Taif road.

\section{Local Geomorphology}

Regionally the dune areas are restricted to wadi courses which cut through the Precambrian igneous and metamorphic rocks of the Arabian Shield. One dune field is located in an inter mountain area along the Khawajat section of Jeddah-Taif road (Location \#1) and the second is situated within Wadi Fatima along the old Jeddah-Makkah road (Location \#2) (Fig. 1). The main rocks that surround the studied dune fields are gray to pink calc-alkalic granites, diorite and granodiorite, and amphibolite schists as mapped by Brown et al. (1979). Sedimentary rocks namely sandstone, arkose, limestone and conglomerate of the Fatima Formation also exist in the vicinity of the second dune field.

The general geomorphology of the western Saudi Arabia was investigated by Brown (1960) but he never got into the details of the dunes in the wadi courses. The dunes in both localities are of the active linear type which support Mainguet's (1984) idea that this dune type exists in rocky areas where the unidirectional regime of the wind is disturbed by the irregular topography. However, the present dunes, which are few hundred meters in length and few tens of meters in width, are different in size from those (1-2 $\mathrm{km}$ in length) described by Mainguet (1984). The dunes are much similar in form and size to those present in Al Nufud sand sea and described as active longitudinal dunes by Whitney et al. (1983) and Shehata (1990). The dunes are also of the reversal type similar to those of the Kelso dunes in the Mojave desert of California and described by Sharp (1966). In the mean time, these dunes are different from the barchan dunes present on the coastal area along Jeddah-Al-Lith road, and those reported by Zaidi (1983) in Khulays area. 


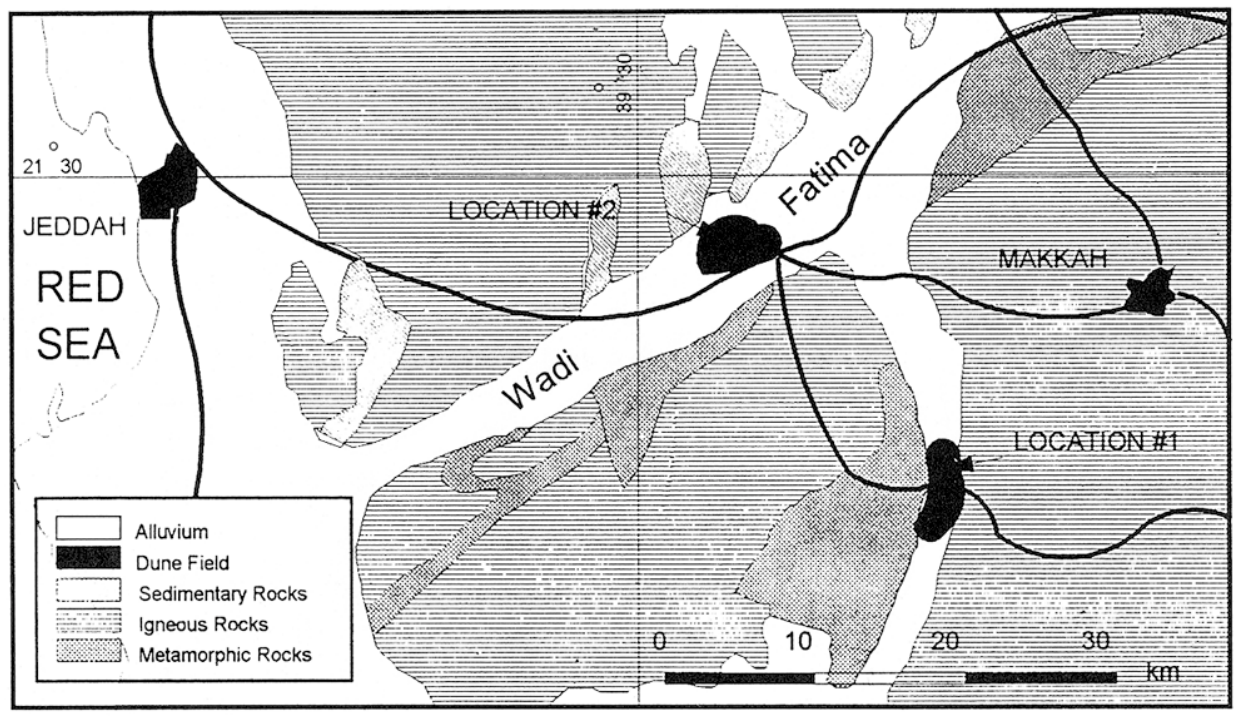

FIG. 1. Simplified geologic and location map (modified after Brown et al., 1979).

The dunes are arranged in staggered forms extending in the N70W to N80W directions with enlarged downwind ends. The crest lines of the dunes are sinuous in nature with a wave length approximately $40 \mathrm{~m}$ in length. A limited study of the internal structures across the crest of one linear dune showed the presence of sand layers dipping in the opposite directions similar to the hypothetical section drawn by McKee (1979). The ripple marks present on the downwind limb of the dune trend in a direction perpendicular to the crest line and are partly covered near the crest. On the windward limb, the ripple marks are parallel to the crest line in some sections and pependicular to it in some others.

The dunes move over a layer of caliche which is locally overlain by a thin sand sheet. This caliche layer, although different in composition, is morphologically similar to the caliche layer present under the dunes in Al Nufud area and the sabkha layer below the dunes in Al Jafurah sand sea. The reasons for the association of these caliche or sabkha layers with the dune areas are yet to be investigated. If the caliche layer is assumed to be a later stage of sabkha salt crust development, the studies of the hydrologic conditions within the dunes may clarify this relationship.

The groundwater in the studied location along the Khawajat road is very shallow as it forms relatively densely vegetated water ponds in the topographically low areas. The city of Makkah waste water which flows to the southeast towards the Red Sea crossing both Jeddah-Taif road and Jeddah-Al-Lith road is the reason in forming a perched shallow groundwater aquifer. Although no water samples were chemically analyzed, the quality of water seems to be suitable for cultivation as some locals established small vegetable fields irrigated by this water. Further investigations are recommended to obtain the aquifer parameters and to test for the groundwater chemical quality. 


\section{Mode of the Reversal Dune Movement}

The prevailing wind direction in Jeddah area is mainly from the NNW, although, gusty winds occasionally come from the south (Anon, 1986). Field observations, however, indicate that the general sand movement in western Saudi Arabia is from northwest to southeast. This is based on the field observations of the barchan dune fields located both along Jeddah-Al-Lith and Jeddah-Madinah roads.

Two dunes, one from each location, were staked both along the crest line and the dune boundaries. Figure 2 shows the arrangement of the stakes on Dune \#10 in location \#1 as an example. The stakes were observed for a period of three months until they had been tampered by the locals. The dunes were also observed during storm periods to predict the way of sand transport. Unfortunately, the removal of the stakes from their locations prevented any further monitoring.

The way that sand drifted during this short monitoring period supports Tsoar (1978) results and Mainguet (1984) observation in north Sebba, Libya. However, it was interesting to notice that the sinuous nature of the crest line played an important role in sand transport. The source of sand transported by wind is the upwind limb of the dune. Part of this sand crosses the dune where the crest line makes a larger angle $\left(>45^{\circ}\right)$ with the prevailing wind direction to form a slip face on the downwind limb. This part is lifted again by the wind and moved along the downwind limb parallel to the crest line (Fig. $3)$. The other part, striking the crest line at a smaller angle $\left(<45^{\circ}\right)$ does not cross the dune and moves along the upwind side again parallel to the crest line. The movement of the two parts tend to move the dune downwind along its crest line. During a two months period, one dune moved $1.6 \mathrm{~m}$, while during a three months period the second dune movement was unnoticeable.

The location of the slip faces were also periodically observed with respect to the crest line. The slip face locations were observed to be discontinuous. They exist alternatively on certain sections along the sinuous crest line while the other sections are in the form of humps without clear brink line. During the monitoring period, the slip faces were reversed at least three times. Slip faces along the dunes are developed on the NE limbs when the wind is more from the WNW direction and along the SW when the wind is from NNW direction. However, the frequency of the wind from the NNW direction exceeds that from the WNW direction which resulted in a lateral movement of the dunes in the $\mathrm{SW}$ direction by values ranging between $1 \mathrm{~m}$ and $2.5 \mathrm{~m}$ during a period of two months.

\section{Properties of the Dune Sand}

\subsection{Mineralogical Composition}

The dune sand of the two locations is quite similar both in color and mineralogical composition. It is grayish yellow in color and consists mainly of quartz, feldspars, biotite and hornblende in addition to chlorite, actinolite, staurolite, sphene, zircon, epidote and opaque minerals as minor constituents. These minerals make an assemblage similar to that of the surrounding igneous, metamorphic and sedimentary rocks. Concentrations 


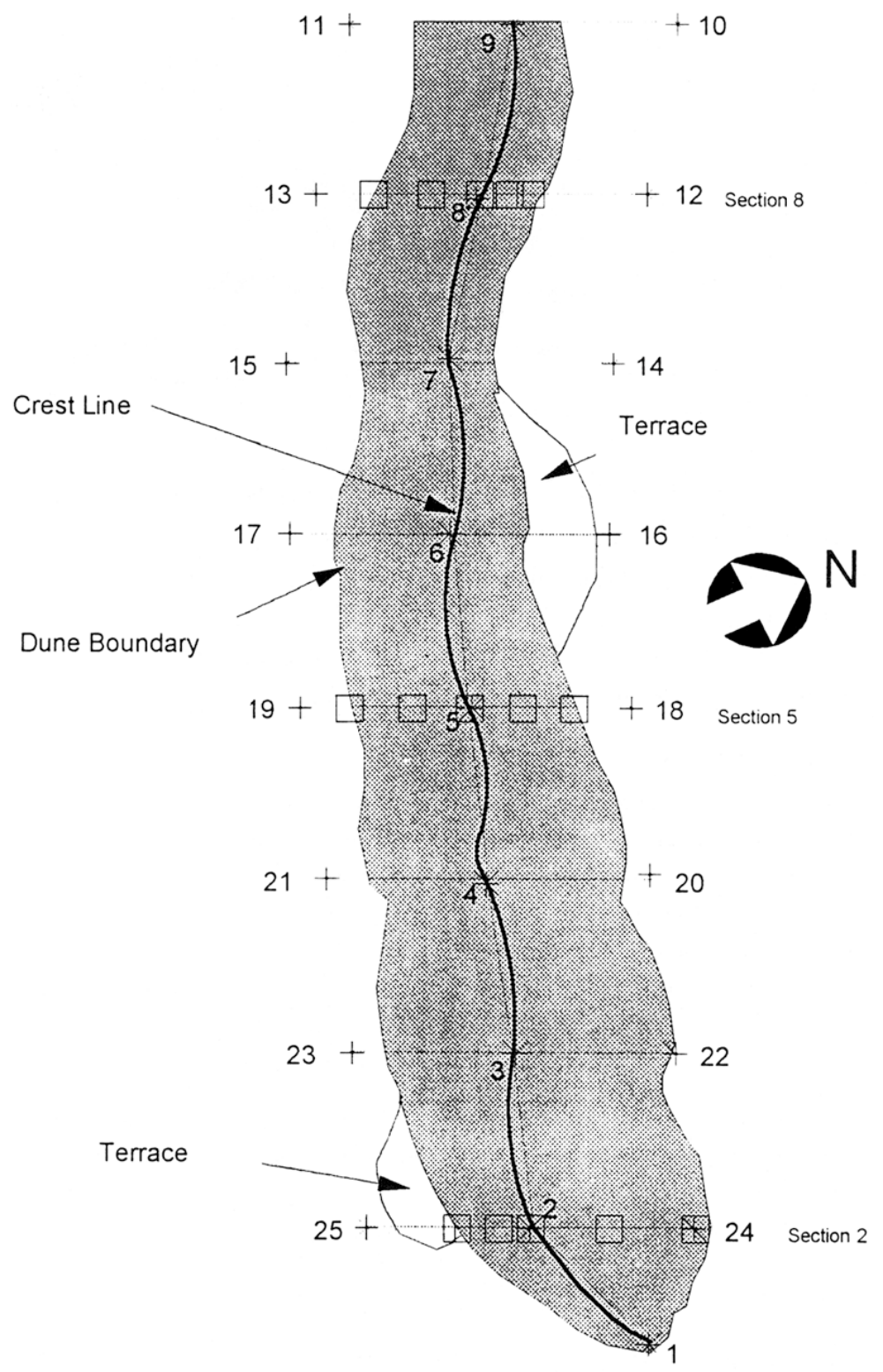

\section{Sample Location}

+ Stake Location

FIG. 2. A sketch diagram for dune \#10 in location \#1 to show the samples and stakes location with respect to the dune geometry. 


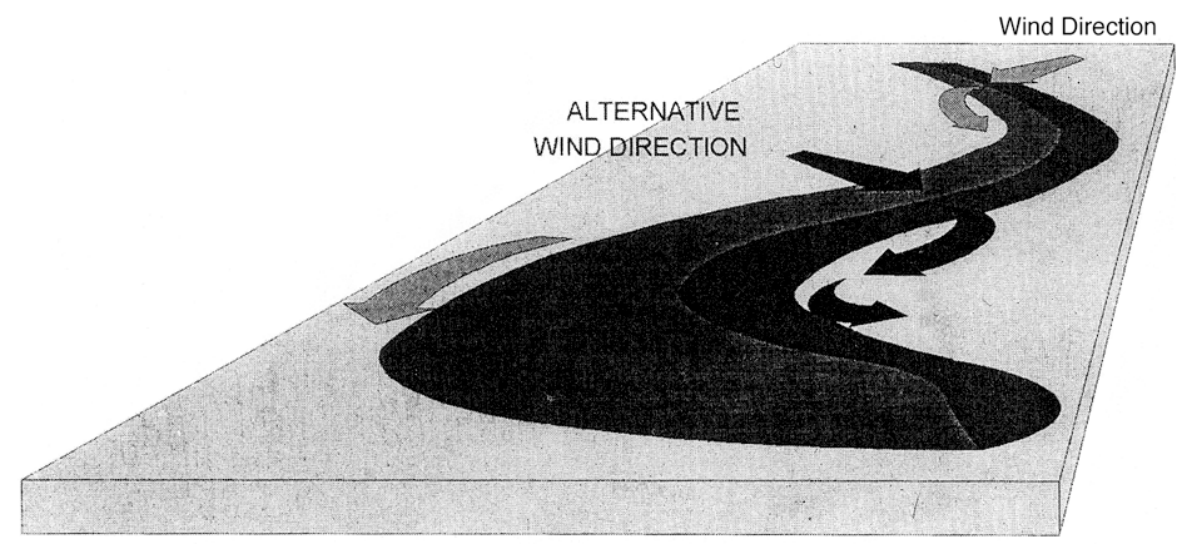

FIG. 3. Block diagram of a reversal linear dune. Arrows show possible sand movement directions.

of biotite are seen on the nebkhas and sand sheets. Along the slip faces, gypsum grains are also observed floating on the dune surface. The heavy mineral content in the studied sand samples ranges between $13.2 \%$ and $17.1 \%$. This percentage is relatively high and suggests the area to be investigated for its economic heavy minerals potentiality.

\subsection{Grain Size Distribution}

Three sets of sand samples were collected across three different dunes, in each location. Each set consists of five samples taken along a profile crossing the dune at its highest point. One sample is taken from the avalanche deposit at the crest, two from the accretion deposits at the plinth of the two faces, and two midways on the limbs. The purpose of these samples is to give the average gradational properties in each location. Three other similar sets of samples were taken along sections crossing one dune (Dune \#10) at different intervals along its length (Fig. 2). The purpose of these samples is to show any variation in the gradational properties within each dune.

Gradation tests were performed according to ASTM (1982) standard method. The engineering gradation parameters such as uniformity coefficient $\left(\mathrm{C}_{\mathrm{u}}\right)$ and coefficient of gradation $\left(\mathrm{C}_{\mathrm{c}}\right)$ were calculated according to Terzaghi and Peck (1968). The sedimentological parameters such as graphic mean size $\left(\mathrm{M}_{\mathrm{z}}\right)$, inclusive graphic standard deviation (sorting) $\left(\sigma_{1}\right)$, inclusive graphic skewness $\left(\mathrm{Sk}_{\mathrm{I}}\right)$ and graphic kurtosis $\left(\mathrm{K}_{\mathrm{G}}\right)$ were calculated according to Folk (1968).

The sand is generally fine grained and could be classified according to the Unified Soil Classification (Terzaghi and Peck, 1967) as poorly graded sand (SP) based on the values of $\mathrm{C}_{\mathrm{u}}$ and $\mathrm{C}_{\mathrm{c}}$. It is well sorted to moderately well sorted at the crest, and moderately well sorted to moderately sorted on the limbs and at the plinths (Figs. 4a \& 4b). The asymmetric distribution of the sorting values across the dune could be related to the timely location of the slip face. Slip face sand is better sorted than the sand in the windward face. The distribution curves are generally near symmetrical although they are oc- 
casionally finely skewed. Although on the average the sand is positively skewed, the crest sand can be negatively skewed (Profiles 5 and 8), or positively skewed (Profile 2). The limbs and troughs are also either negatively skewed or positively skewed. These findings contradicts Ahlbrandt (1979) in his investigation on the barchan dunes where crests tend to be better sorted than windward and slip faces, and have positive skewness. It also contradicts Folk (1962) statement that negative skewness are seldom encountered in eoilian sand. The results indicate that negative skewness is present which could be due to the reversal character of the linedar dunes during their movement. This reversal behavior may cause the continuous mixing up of the crest sand with the limbs and troughs sand. The sand is generally mesokurtic, however, at the crest it is mesokurtic to platykurtic, while it is platykurtic to leptokurtic on the limbs and at the plinths (Figs. 5a, 5b $\& 5 \mathrm{c}$ ). Windward sand tends to have higher kurtosis (more leptokurtic) than slip face sand which agrees with the results reported by Folks (1971) and Binda (1983). The grain size parameters varies slightly along the crest line of dune \#D10 (Fig. 5d). The grain size gets finer and the uniformity coefficient gets smaller towards the nose. The relationship between the graphic mean size, kurtosis and uniformity coefficient is worth observing and further investigation. Kurtosis values are found to, more or less, follow the trend of the uniformity coefficient while the graphic mean size values are mirror image to it.
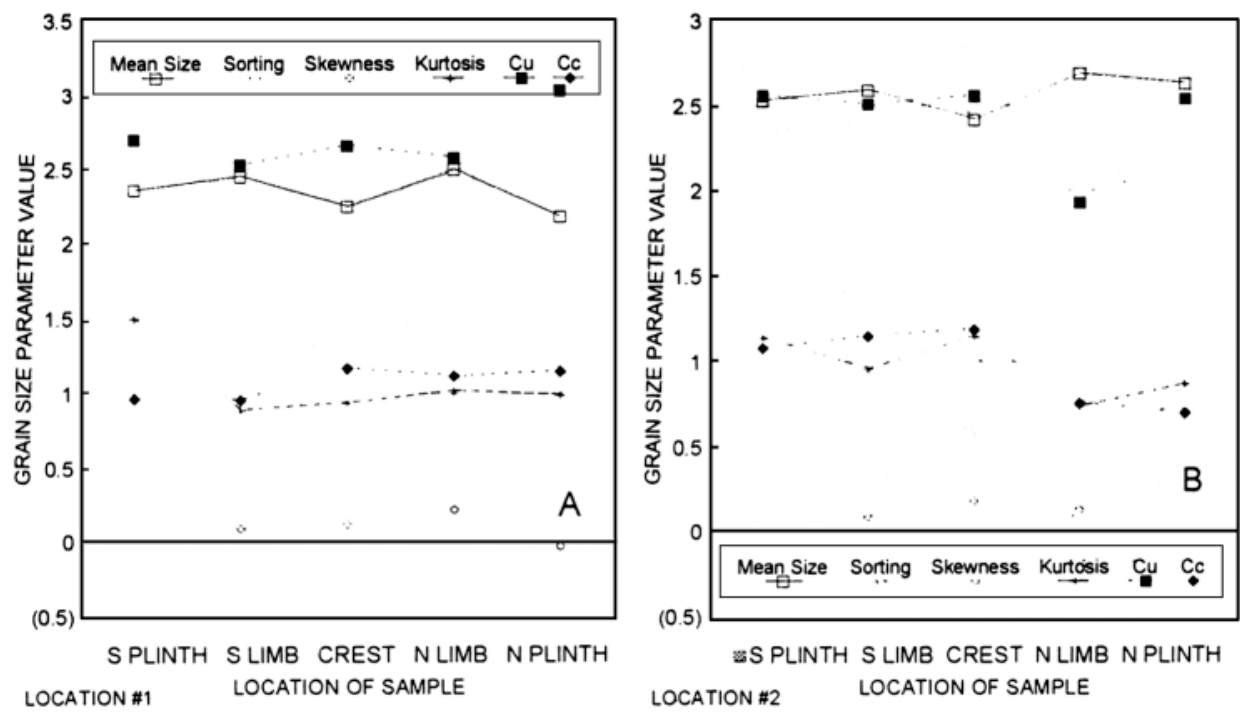

FIG. 4. Average grain size parameters in: [A] Location \#1; [B] Location \# 2.

\subsection{Penetration Resistance}

The resistance to cone penetration was performed using the Mackintosh probe which consists of a cone $27 \mathrm{~mm}$ in diameter, driven into the ground by a $4 \mathrm{~kg}$ hammer at a 28 $\mathrm{cm}$ fall height. The number of blows required to drive the cone for $100 \mathrm{~mm}(\mathrm{M})$ is recorded and may be used as an index of the penetration resistance (Clayton et al., 1984). The probe is also a good tool to map the subsurface stratigraphic sequence relative to the degree of sand compactness. Sabtan and Shehata (1994) concluded that this probe, being light, is considered to be a fast and reliable tool to explore most soil types. 

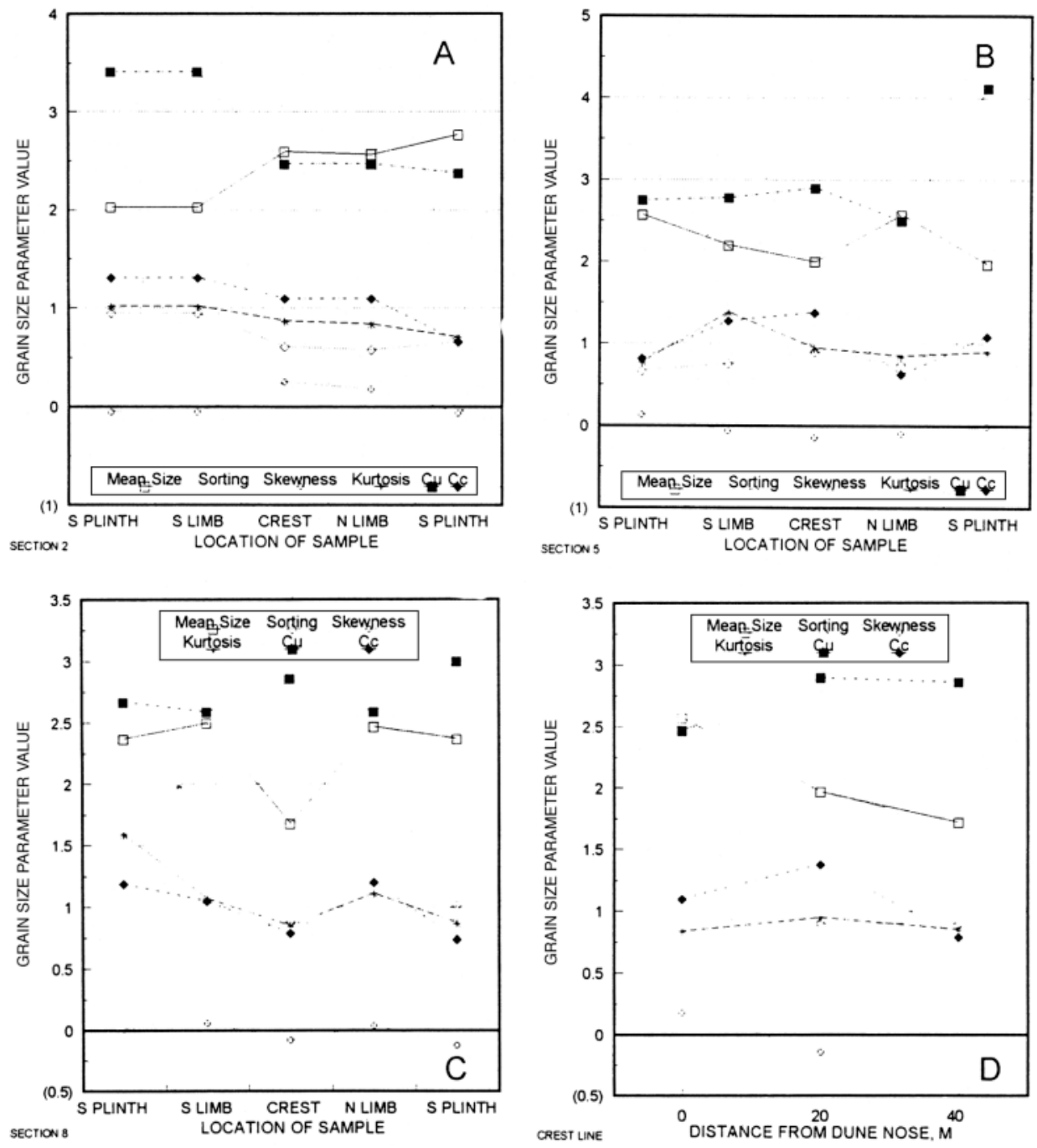

FIG. 5. Grain size parameters, location \#1, dune \#D10, across: [A] Section 2; [B] Section 5; [C] Section 8; [D] Crest line. 
Using the results of the penetration resistance tests (Fig. 6a) performed in five locations along a section \#2 dune \#10 (Fig. 2), a cross section could be constructed (Fig. $6 \mathrm{~b})$. This cross section shows that the avalanche deposits have a much lower penetration resistance and consequently lower relative density than the accretion deposits. Denekamp and Tsur-Lavie (1981) measured the relative density of dune sand following the ASTM D1557 designation and reached the same conclusion. The cross section also shows minor successive changes in the penetration resistance in the avalanche deposits which is probably due to the relative difference in the degree of compaction of the successive layers. The penetration resistance starts to increase with depth due to the presence of accretion deposits underneath it. These findings suggested the deviation from the cross sections presented by Bagnold (1941) and McKee (1979) for barchan dunes and allowed the reconstruction of a cross section for the linear dunes as predicted from the penetration resistance tests (Fig. 6b).

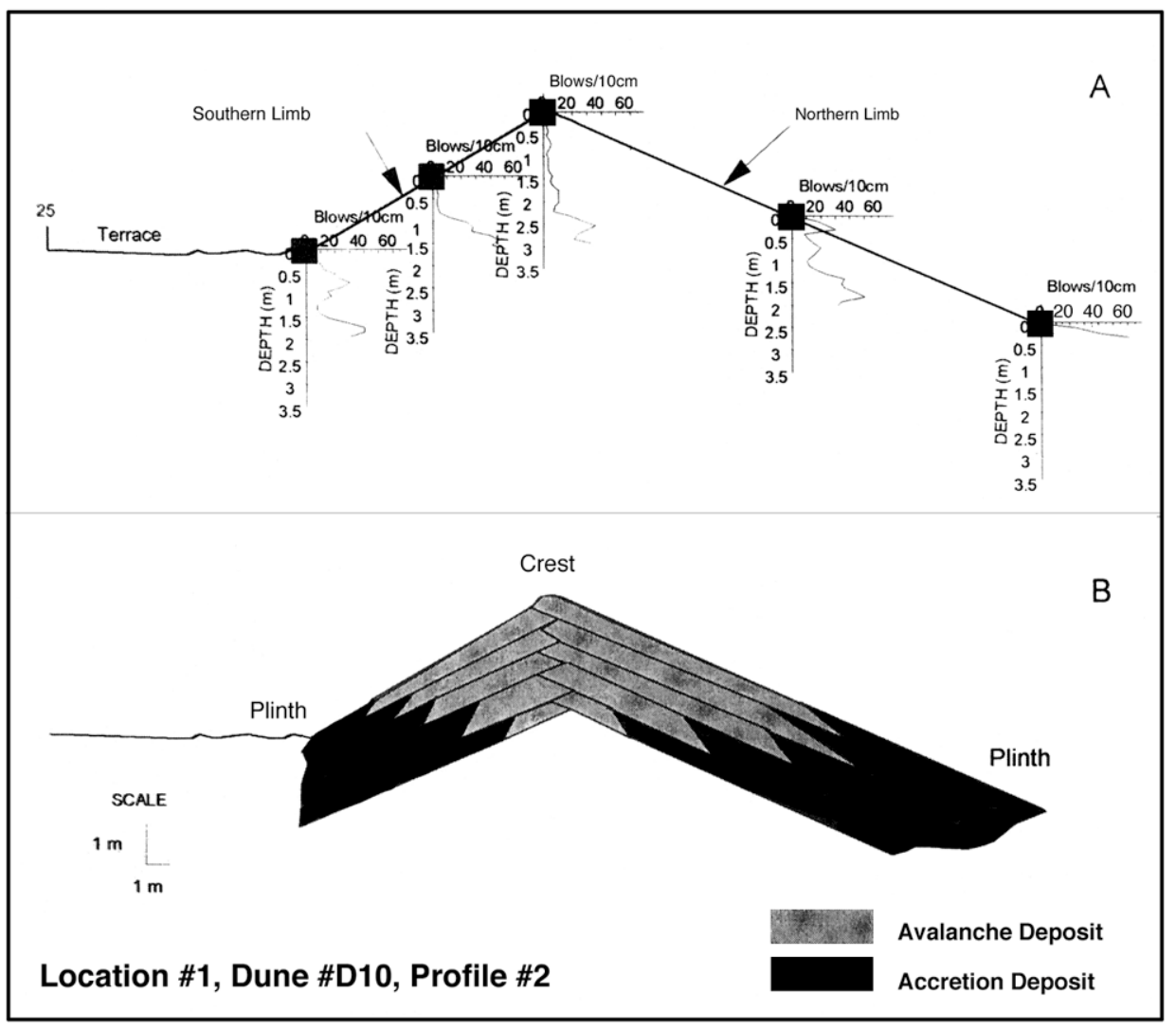

FIG. 6. [A] Mackintosh probe penetration resistance data. [B] Suggested cross section across a linear dune. 


\section{Comparison with Al Jafurah and Al Nufud Dunes}

The rock composition in the vicinity of the dune fields normally influences the composition of the dune sand. For example, the heavy minerals concentration in the sand from the two studied locations consists of an average of $13.2 \%$ and $17.1 \%$ respectively which exceeds the heavy minerals concentration in Al Jafurah sand sea $(0.96 \%$ to $1.25 \%$ ) (Anon, 1990) existing within a limestone terrain. The studied sand is grayish yellow in color and is different from Al Nufud and Ad Dahna reddish sand substantiating the difference in origin.

The grain size of the linear dunes is generally similar to the barchan dunes but finer than the other dune forms (Table 1). The sorting is higher, the skewness is lower, and the uniformity coefficient is lower. No clear variations in both the kurtosis and the coefficient of gradiation values among the different dune forms.

TABlE 1. Comparison between average grain size parameters in Jeddah linear dunes' sand and other eolian sand forms in the Kingdom.

\begin{tabular}{|l|r|r|r|c|c|c|c|l|}
\hline Dune type, location & $\mathrm{M}_{\mathrm{d}}$ & $\mathrm{M}_{\mathrm{z}}$ & $\sigma_{1}$ & $\mathrm{Sk}_{1}$ & $\mathrm{~K}_{\mathrm{G}}$ & $\mathrm{C}_{\mathrm{u}}$ & $\mathrm{C}_{\mathrm{c}}$ & Reference \\
\hline Linear dunes, Location \#1 & 0.19 & 0.20 & 0.73 & 0.08 & 1.07 & 2.70 & 1.07 & This study \\
Linear dunes, Location \#2 & 0.20 & 0.17 & 0.69 & 0.11 & 0.97 & 2.42 & 0.98 & This study \\
Linear dunes, Al Nufud & 0.27 & 0.22 & 0.35 & 0.17 & 0.92 & 1.35 & 1.29 & Shehata (1990) \\
Barchan dunes, Al Nufud & 0.30 & 0.26 & 0.61 & 0.47 & 1.07 & 3.83 & 1.33 & Shehata (1990) \\
Barchan dunes, Al Jafurah & 0.24 & 0.22 & 0.59 & 0.26 & 1.00 & 1.82 & 1.56 & Bader, et al. (1994) \\
Barchan dunes, Wadi Khulays & - & 0.17 & 0.63 & 0.05 & 0.90 & - & - & Binda (1983) \\
Parabolic dunes, Al Jafurah & 0.30 & 0.26 & 0.94 & 0.23 & 0.89 & 2.17 & 1.52 & Bader, et al. (1994) \\
Dome dunes, Al Jafurah & 0.24 & 0.23 & 0.96 & 0.06 & 0.88 & 2.04 & 1.36 & Bader, et al. (1994) \\
Dome sand, Wadi Dawasir & 0.29 & - & 1.8 & 0.80 & - & 4.4 & - & Hotzl, et al. (1978) \\
Sand Pit, Al-Hofuf & 0.45 & - & 1.7 & 0.83 & - & 4.8 & - & Hotzl, et al. (1978) \\
Dune sand, Ad Dahna & 0.32 & - & 1.3 & 0.67 & - & 4.5 & - & Hotzl, et al. (1978) \\
Eolian sand, Wadi Hanifah & 0.35 & - & 1.5 & 0.73 & - & 4.0 & - & Hotzl, et al. (1978) \\
\hline
\end{tabular}

\section{Possible Interaction with Human Activities}

The rate of the linear dune movement, based on the short monitoring period, is relatively slow as compared to the barchan dunes. The reversal nature of the dunes and the energy consumed in their winding movement could be a reason to retard their forward movement.

The sections of the highways crossing the two dune fields in the studied locations are running either parallel or at low intersection angle to the dune crest lines. This fact as well as the slow nature of the dunes minimized the possible blown sand or dune migration hazards on the highways. However, the possibility of drifting sand hazard still exist and some remedial measures should be considered. Groundwater level is very shallow in location \#1 due to the runoff of the waste water originated at the city of Makkah. Similarly groundwater level is expected to be relatively shallow in Wadi Fatima area 
(location \#2). It is therefore suggested to establish a forest in each of these locations and in particular in location \#1. This forest will grow with the minimum effort of care, and will have the capability to retard the sand movement and control the dunes migration. The presence of vegetation will improve the cultivation properties of the existing clean sandy soil. The forest will also consume a large volume of the waste water and prevent it from forming ponds along both the Khawajat and Jeddah-Al-Lith roads. Further investigations are necessary to evaluate the aquifer productivity and water quality. It is also necessary to select the feasible tree species that may grow under the existing conditions.

\section{Conclusions and Recommendations}

The main sand dune type in the inter-mountain areas in central Tihama is the reversible linear as encountered in two inter mountain dune fields. These dunes follow a winding movement as they move along their crest lines. The reversal nature of the dunes was substantiated by the cone penetration resistance tests and by some of the grain size parameter values.

The mineralogy of the dunes is different than that of the other sand seas and the high percentage of heavy minerals content worth further investigation and economic evaluation. It is also recommended for the engineers to use some of the geological grain size distribution parameters as they better describe the sand.

The dunes pose little hazard on the sections of Jeddah-Taif and Jeddah-Makkah highways crossing locations \#1 and \#2 respectively because of their respective directions. However, the establishment of a forest along Jeddah-Taif road is recommended to not only control any sand drifting hazard but also to utilize the waste water ponding along both this road and Jeddah-Al-Lith road.

\section{References}

Ahlbrandt, T.S. (1979) Textural parameters of eolian deposits. in: A Study of Global Sand Seas, E.D. McKee (ed.), U.S. Geol. Surv. Prof. Paper 1052, pp. 21-51.

Al-Saud, M.M.S. (1988) Drifting sand and its grain size characteristics, Ad Dahna desert along RiyadhDammam road [in Arabic]. M.Sc. Thesis, King Saud University, Riyadh, Saudi Arabia.

Anon (1982) Standard method for particle size analysis of soils. ASTM designation D422-63, Easton, MD, pp. 112-121.

- (1986) Saudi Arabian Wind Energy Atlas. UPM Printing Press, Saudi Arabia, 67 p.

(1990) Geomorphology and sand dunes movement. In Eolian Sand Control at King Fahd Military City, Dhahran, Project. No. 23044. Final Report Submitted to Ministry of Defense \& Aviation, Riyadh.

Anton, D. and Vincent, P. (1986) Parabolic dunes of the Jafurah Desert, Eastern Province, Saudi Arabia. Journal of Arid Environments, 11: 187-198.

Bader, T., Shehata, W., Lofti, H., Ali, A. and Abdallah, M. (1994) Engineering and mineralogical properties of dune sand, Eastern Province, Saudi Arabia. Presented to the 2nd Geotech. Eng. Conf., Cairo, April 1994.

Bagnold, R.A. (1941) The Physics of Blown Sand and Desert Dunes. Chapman \& Hall, London, 265 p.

Binda, P.L. (1983) Grain size study of some eolian sands from Saudi Arabia. KAU, Faculty of Earth Science Bull., 5: 73-82.

Brown, G.F. (1960) Geomorphology of western and central Saudi Arabia. Proc. 21st International Geologic Congress, Copenhagen, Part XXI, pp. 150-159. 
Jackson, R.O., Bogue, R.G. and Maclean, W.H. (1979) Geology of the Southern Hijaz Quadrangle. Saudi Arabia Deputy Ministry for Mineral Resources Geologic Map GM-210-A.

Denekamp, S.A. and Tsur-Lavie, Y. (1981) The study of relative density in some dune and beach sands. Eng. Geol., 17: 159-173.

Edgell, H.S. (1990) Evolution of the Rub' al Khali Desert. Journal of King Abdulaziz University Earth Sciences, 3: 109-126.

El-Nozahy (1993) Grain morphology, grain size and mineralogical composition of linear dune sands, Ad Dahna Desert, Saudi Arabia. N. Jb. Geol. Palaont. Abh., Bd., 188(3): 265-288.

Folk, R.L. (1962) Of skewnesses and sands. Jour. Sed. Petrol., 32: 145-146. (1968) Petrology of Sedimentary Rocks. Hemphill's Drawer M. University Station, Austin TX, 170. (1971) Longitudinal dunes of the northwestern edge of the Simpson Desert, Northern Territory, Australia, 1-Geomorphology and grain size relationships. Sedimentology, 16: 5-54.

Fryberger, S.G., Al-Sari, A.M., Clisham, T.J., Rizvi, S.A. and Al-Hinai, K.G. (1984) Wind sedimentation in the Jafurah sand sea, Saudi Arabia. Sedimentology, 31: 413-431.

Goudie, A. and Wilkinson, J. (1977) The Warm Desert Environment. Cambridge University Press, 88 p.

Hotzl H., Kramer, F. and Maurin, V. (1978) Quaternary sediments. in: Quaternary Period in Saudi Arabia, S.S. Al-Sayari and J.G. Zotl (eds.), Springer Verlag, Vienna, pp. 264-301.

Mainguet, M. (1984) A classification of dunes based on eolian dynamics and the sand budget. in: Deserts and Arid Lands, F. El-Baz (ed.), Martinus Nijhoff Publishers, pp. 31-58.

McClure, H.A. (1978) Ar Rub' al Khali. in: Quaternary Period in Saudi Arabia, S.S. Al-Sayari and J.G. Zotl (eds.), Springer Verlag, Vienna, pp. 252-263.

(1984) Late Quaternary Paleoenvironments of the Rub' al Khali. Ph.D. Thesis, University College, London.

McKee, E. (1979) Sedimentary structures in dunes. in: A Study of Global Sand Seas, E. McKee (ed.), U.S. Geol. Surv. Professional Paper 1052, pp. 83-133.

Sabtan, A.A. and Shehata, W.M. (1994) Mackintosh probe as an exploration tool. Bull. Intern. Assoc. Eng. Geol., 50: 89-94.

Sharp, R.P. (1966) Kelso dunes, Mohave Desert, California. Geol. Soc. America Bull., 77(10): 1045-1073.

Shehata, W.M. (1990) Report on trip to Hail. Tech. Report submitted to Geology \& Minerals Division, KFUPM/RI, 9 p.

_, Bader, T., Irtem, O., Ali, A., Abdallah, M. and Aftab, S. (1992) Rate and mode of barchan dunes advance in the central part of the Jafurah sand sea. Journal of Arid Environments, 23: 1-17.

Terzaghi, K. and Peck, R.B. (1968) Soil Mechanics in Engineering Practice. John Wiley \& Sons, New York.

Tsoar, H. (1978) The dynamics of longitudinal dunes. Final Tech. Report, Eur. Res. Off., U.S. Army, London, $171 \mathrm{p}$.

Vincent, P.J. (1984) Particle size variation over a transverse dune in the Nafud as Sirr, central Saudi Arabia. Jour. Arid Envir., 7: 329-336.

Whitney, J.W. (1981) Saudi Arabia's stable sand seas [abs.]. Geological Society of America Abstracts with Program, 13: 580.

—, Faulkender, D.J. and Rubin, M. (1983) The environmental history and present condition of Saudi Arabia's sand seas. Saudi Arabia Deputy Ministry for Mineral Resources, Open-File Report 83-749, $39 \mathrm{p}$.

Zaidi, S.M.S. (1983) Landforms and geomorphic evolution of Wadi Khulays area, Western Saudi Arabia. KAU, Faculty of Earth Science Bull., 5: 153-166. 


\title{
دراسة تكون الكثبان الرملية جنوب شرق مدينة جـدة ، المملـكة العربيــة السعوديـــة
}

\author{
وليم مكرم شحاته ، عبد اللّه بن سبتان و محمود غزال

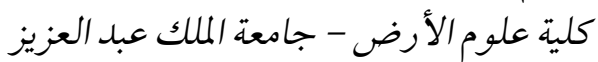

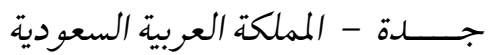

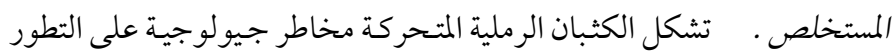

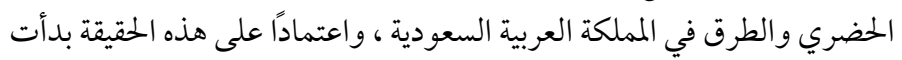

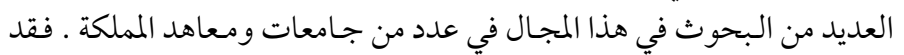

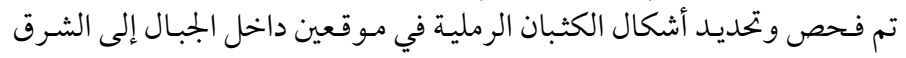

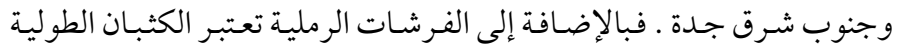

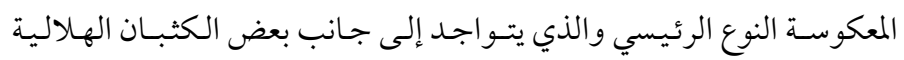
الصغيرة.

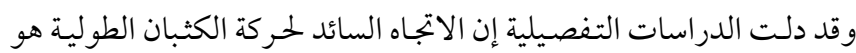

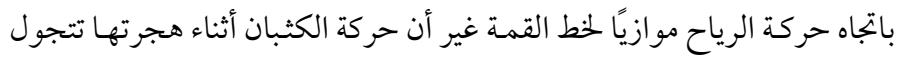

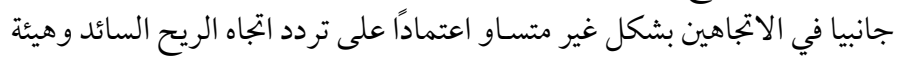

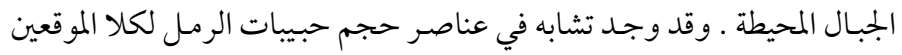

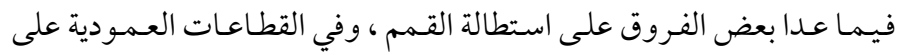

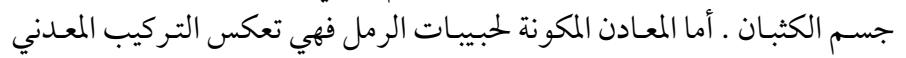

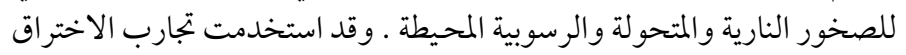

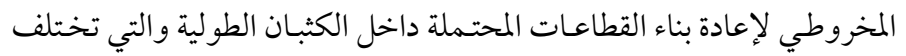

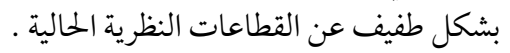

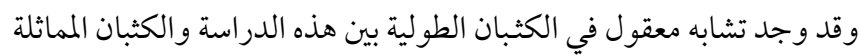

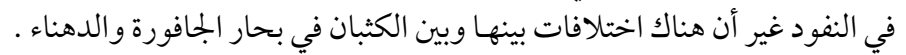

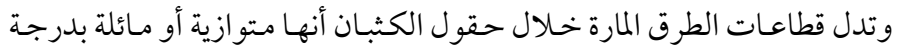

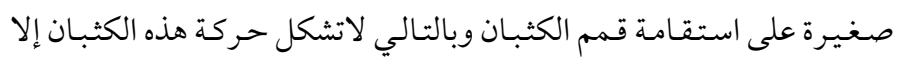

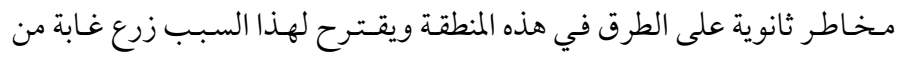

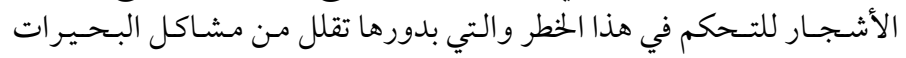
الر اكدة لمياه الصرف الصحي في المذار المنطقة والتي 